\title{
Characterize the Moisture Distribution Pattern in Drip Irrigation under Sandy Loam Soil
}

\author{
Mallikarjun Reddy $^{1 *}$, M.S. Ayyanagowdar ${ }^{2}$ and M. Nemichandrappa ${ }^{3}$ \\ ${ }^{1}$ Department of Agricultural Engineering, AC, Kalaburgi, India \\ ${ }^{2}$ IDE Department, CAE, UAS, Raichur, India \\ ${ }^{3}$ SWE Department, AC, Bhimarayana gudi, India \\ *Corresponding author
}

\section{A B S T R A C T}

\begin{tabular}{|l|}
\hline Ke y w or d s \\
Drip irrigation, \\
Sandy loam soil, \\
Crop \\
\hline Article Info \\
\hline Accepted: \\
23 March 2018 \\
Available Online: \\
10 April 2018 \\
\hline \hline
\end{tabular}

The ever increasing population growth rate has compelled to maximize food production per unit of water used, as water is major resource for agricultural production. The micro irrigation system has now become indispensible for increase in crop production as water is directly applied to the root zone of the plant. Thus micro irrigation minimizes conventional losses due to deep percolation, runoff and soil evaporation and also permits the effective utilization of fertilizers, pesticides and other water soluble chemicals along with irrigation water with better crop response. A perfect design of trickle irrigation requires knowledge of water distribution pattern in soil. The moisture distribution pattern will determine effectiveness of drip irrigation system in field conditions. One of the important parameter affecting water distribution to the plant in the field condition is hydraulic characteristics of drip irrigation system, therefore, it is essential to understand hydraulic performance of drip irrigation system in relation to soil moisture distribution.

\section{Introduction}

Limited resources of fresh water and high demand for water of high quality allocated to agriculture led many countries, scientific institutions, and researchers to direct their work toward increasing the water use efficiencies. Most countries in arid and semiarid regions, such as Egypt, are concerned by two major problems: (1) Reduction of highquality water resources allocated to agriculture, and (2) Increasing groundwater contamination, especially by nitrate and heavy metals, which apparently stems from agriculture activities (Addiscott, 1996).
Drip irrigation is widely known as the most efficient irrigation system that save a lot of water and overcomes the problem of losing water through deep percolation (Nakayama and Bucks, 1986). In drip irrigation water is applied through a point source known as dripper or emitter. In on-surface drip irrigation, a small wetted bulb is created underneath each dripper. The volume of wetted soil and the pattern of water front, its area, and velocity are special parameters that affect the water distribution in both vertical and horizontal directions. These parameters are indispensable for designing and operating the drip irrigation systems. Moreover, they are 
affected by both the amount of irrigation water and the discharge of the drippers, as well as the soil physical properties (Acar, et al., 2009). Water distribution in soil irrigated with surface drip irrigation system depends on many factors such as soil properties, as well as the system properties such as discharge of drippers and the amount of water applied per irrigation (Clark et al., 1993) and water uptake by plants (Coelho and Or, 1996; Assouline et al., 2002). The best management of the drip irrigation system is to either control or adjust to as many of these factors as possible. Simonne, et al., (2006) reported that with increasing the amount of irrigation water applied to a fine sandy soil the depth and width of wetted zone significantly increased and resulted in emitter-to-emitter coverage.

The same concept was emphasized by Elmaloglou and Diamantopoulos (2008) whom results revealed that, for the same soil, the vertical component of the wetting front is greater for smaller discharge rate than for the higher one. They also mentioned that this difference was practically eliminated at the total simulation time which was defined as the time needed to reach the initial average water content in the root zone.

\section{Materials and Methods}

Field study was conducted in New Orchard of Main Agricultural Research Station, University of Agricultural Sciences, Raichur. This place is located in $16^{\circ} 15^{\prime} \mathrm{N}$ latitude and $77^{\circ} 20^{\prime} \mathrm{E}$ longitude and is at an elevation of $389 \mathrm{~m}$ above mean sea level (MSL).

\section{Results and Discussion}

\section{Soil properties}

The experimental field has sandy loam textured soil and a $\mathrm{pH}$ of 7.6 and a good electrical conductivity of $0.26 \mathrm{dS} \mathrm{m}^{-1}$

\section{Infiltration rate}

Infiltration rate was measured by using double ring infiltrometer and was found to be $1.72 \mathrm{~cm}$ $\mathrm{h}^{-1}$.

\section{Soil texture}

The texture of the soil was found using international pipette method. Under the textural classification the soil was found to be sandy loam. The texture compositions of the soil in per cent are given in the Table 1.

\section{Moisture movement}

The moisture movement reading was recorded from the start of irrigation at regular interval of $10 \mathrm{~min}$ for $2.40 \mathrm{hr}$ duration.

\section{Relationship between radial and vertical water movement}

Graphs were plotted to show the relationship between horizontal and vertical water movement. Proper equations were fitted for the prediction of water movement. The graphs were predicted in Figure 1 and 2.

\section{Prediction of the vertical and horizontal water movements}

The horizontal and vertical water front advances were predicted using the developed equations (Table 3). The predicted values were tested for their goodness of fit using chisquare test. The statistic for chi-square test is given by

$x^{2}=\Sigma\left(\frac{\left(\mathrm{O}_{i}-E_{l}\right)^{2}}{\mathrm{E}_{i}^{2}}\right)$ Eqn.3.1

Where,

$\mathrm{O}_{\mathrm{i}}=$ Observed values $(\mathrm{i}=1,2,3 \ldots \mathrm{i})$

$\mathrm{E}_{\mathrm{i}}=$ Estimated values $(\mathrm{i}=1,2,3 \ldots \mathrm{i})$

$\mathrm{N}=$ number of observations 
Table.1 Soil characteristics of the experimental field

\begin{tabular}{|c|l|c|}
\hline Soil characteristics & Particulars & Composition \\
\hline Textural composition & Sand, (per cent) & 74.45 \\
& Silt, (per cent) & 11.42 \\
& Clay, (per cent) & 14.13 \\
\hline Physical characters & Bulk density, g cc & 1.58 \\
\cline { 2 - 3 } & Field capacity, per cent & 19.04 \\
\cline { 2 - 3 } & Permanent wilting point, per & 11.34 \\
& cent & \\
\cline { 2 - 3 } & Infiltration rate, $\mathrm{cm} \mathrm{h}^{-1}$ & 1.72 \\
\hline
\end{tabular}

Table.2 Horizontal and vertical water movement at different time intervals for sandy loam soil

\begin{tabular}{|c|}
\hline Time, $(\mathbf{m i n})$ \\
\hline 10 \\
\hline 20 \\
\hline 30 \\
\hline 40 \\
\hline 50 \\
\hline 60 \\
\hline 70 \\
\hline 80 \\
\hline 90 \\
\hline 100 \\
\hline 110 \\
\hline 120 \\
\hline 140 \\
\hline
\end{tabular}

\begin{tabular}{|c|c|}
\hline $\begin{array}{c}\text { Horizontal wetted } \\
\text { zone radius, }(\mathbf{c m})\end{array}$ & $\begin{array}{c}\text { Vertical wetted zone depth, } \\
(\mathbf{c m})\end{array}$ \\
\hline 9.1 & 3.21 \\
\hline 13.4 & 6.5 \\
\hline 15.45 & 11.82 \\
\hline 18.21 & 12.87 \\
\hline 20.22 & 15.23 \\
\hline 21.67 & 17.56 \\
\hline 22.45 & 18.93 \\
\hline 22.89 & 19.56 \\
\hline 23.54 & 21.11 \\
\hline 24.78 & 22.67 \\
\hline 25.5 & 23.23 \\
\hline 26.12 & 24.44 \\
\hline 28.22 & 27.5 \\
\hline
\end{tabular}

Table.3 Different model for horizontal water movement

\begin{tabular}{|c|}
\hline Model \\
\hline Exponential \\
\hline Linear \\
\hline Logarithmic \\
\hline Polynomial \\
\hline Power \\
\hline
\end{tabular}

\begin{tabular}{|l|l|}
\hline \multicolumn{1}{|c|}{ Equation } & $\mathbf{R}^{2}$ \\
\hline $\mathrm{Y}=12.30 \mathrm{e}^{0.006 \mathrm{x}}$ & 0.806 \\
\hline $\mathrm{Y}=0.127 \mathrm{x}+11.80$ & 0.912 \\
\hline $\mathrm{Y}=7.175 \ln (\mathrm{x})-8.074$ & 0.991 \\
\hline $\mathrm{Y}=-000 \mathrm{x}^{2}+0.268 \mathrm{x}+8.043$ & 0.976 \\
\hline $\mathrm{Y}=3.872 \mathrm{x}^{0.406}$ & 0.983 \\
\hline
\end{tabular}


Table.4 Different model for vertical water movement

\begin{tabular}{|c|}
\hline Model \\
\hline Exponential \\
\hline Linear \\
\hline Logarithmic \\
\hline Polynomial \\
\hline Power \\
\hline
\end{tabular}

\begin{tabular}{|l|c|}
\multicolumn{1}{|c|}{ Equation } & $\mathrm{R}^{2}$ \\
\hline $\mathrm{Y}=6.235 \mathrm{e}^{0.012 \mathrm{x}}$ & 0.752 \\
\hline $\mathrm{Y}=0.168 \mathrm{x}+5.281$ & 0.944 \\
$\mathrm{Y}=9.269 \ln (\mathrm{x})-20.11$ & 0.98 \\
\hline $\mathrm{Y}=-0.001 \mathrm{x}^{2}+0.312 \mathrm{x}+1.429$ & 0.983 \\
\hline $\mathrm{Y}=0.704 \mathrm{x}^{0.758}$ & 0.961
\end{tabular}

Table.5 Observed and predicted values of horizontal and vertical water movement at different time intervals for sandy loam soil

\begin{tabular}{|c|c|c|c|c|}
\hline \multirow[t]{2}{*}{ Time, (min) } & \multicolumn{2}{|c|}{$\begin{array}{l}\text { Horizontal wetted zone radius, } \\
\qquad(\mathrm{cm})\end{array}$} & \multicolumn{2}{|c|}{ Vertical wetted zone depth, $(\mathrm{cm}$} \\
\hline & Measured & Predicted & Measured & Predicted \\
\hline 10 & 9.1 & 8.45 & 3.21 & 4.45 \\
\hline 20 & 13.4 & 13.42 & 6.5 & 7.27 \\
\hline 30 & 15.45 & 16.33 & 11.82 & 9.89 \\
\hline 40 & 18.21 & 18.39 & 12.87 & 12.31 \\
\hline 50 & 20.22 & 19.99 & 15.23 & 14.53 \\
\hline 60 & 21.67 & 21.30 & 17.56 & 16.55 \\
\hline 70 & 22.45 & 22.41 & 18.93 & 18.37 \\
\hline 80 & 22.89 & 23.37 & 19.56 & 19.99 \\
\hline 90 & 23.54 & 24.21 & 21.11 & 21.41 \\
\hline 100 & 24.78 & 24.97 & 22.67 & 22.63 \\
\hline 110 & 25.5 & 25.65 & 23.23 & 23.65 \\
\hline 120 & 26.12 & 26.28 & 24.44 & 24.47 \\
\hline 130 & 27.5 & 26.85 & 26.12 & 25.09 \\
\hline 140 & 28.22 & 27.38 & 27.5 & 25.51 \\
\hline$\chi^{2}$ & \multicolumn{2}{|c|}{0.99} & \multicolumn{2}{|c|}{0.99} \\
\hline Df & \multicolumn{2}{|c|}{13} & \multicolumn{2}{|c|}{13} \\
\hline
\end{tabular}

Fig.1 Relationship between radial and vertical water movement

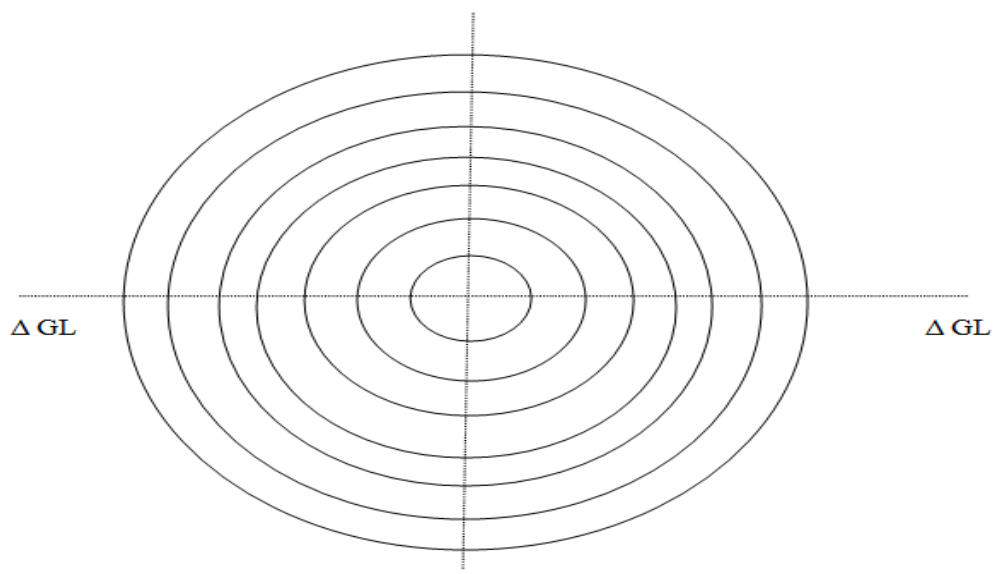


Fig.2 Grid points from which the water front advances was recorded

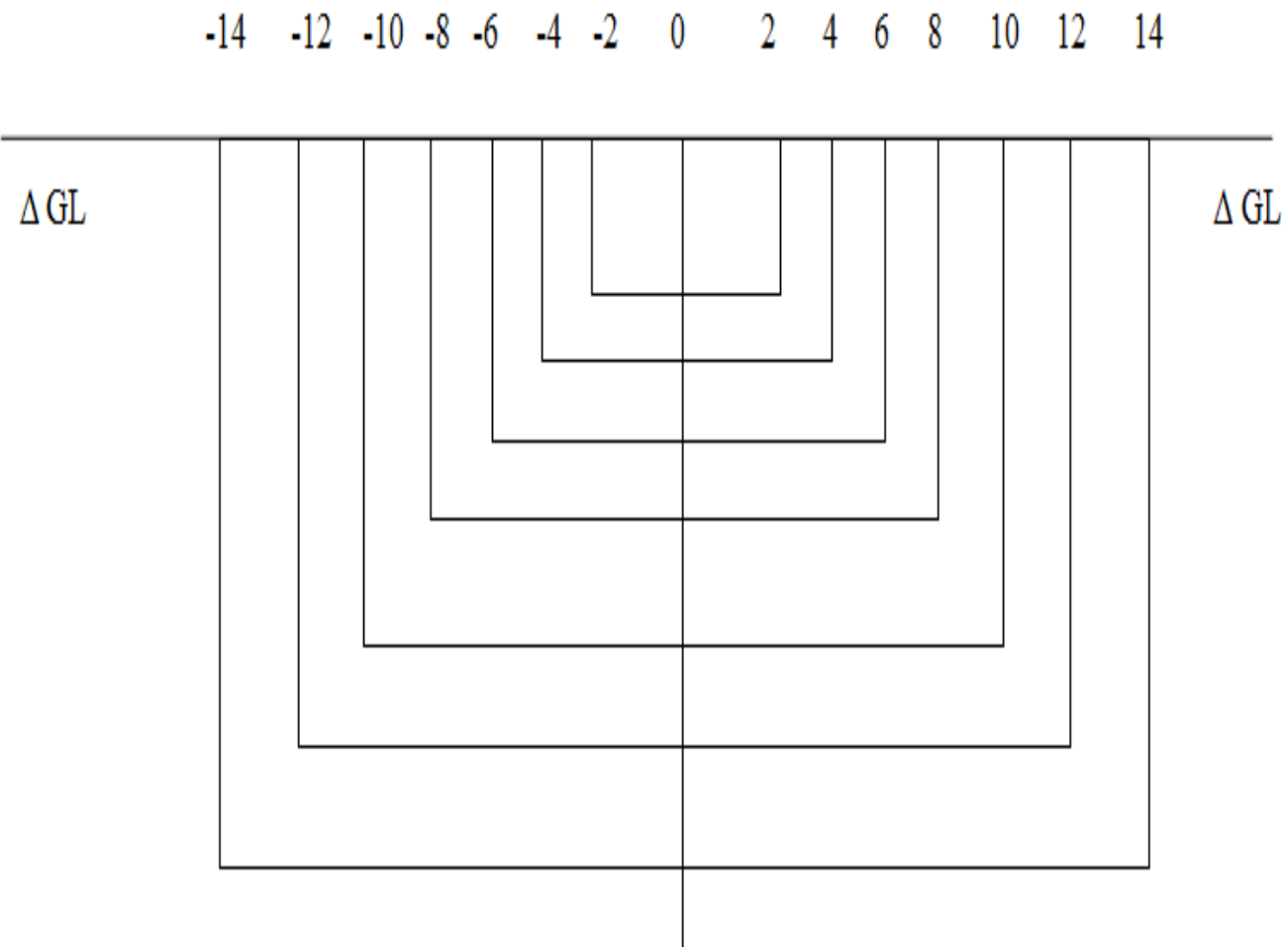

Fig.3 Schematic diagram showing wetting pattern from two parallel surface drip lines for sandy loam soil

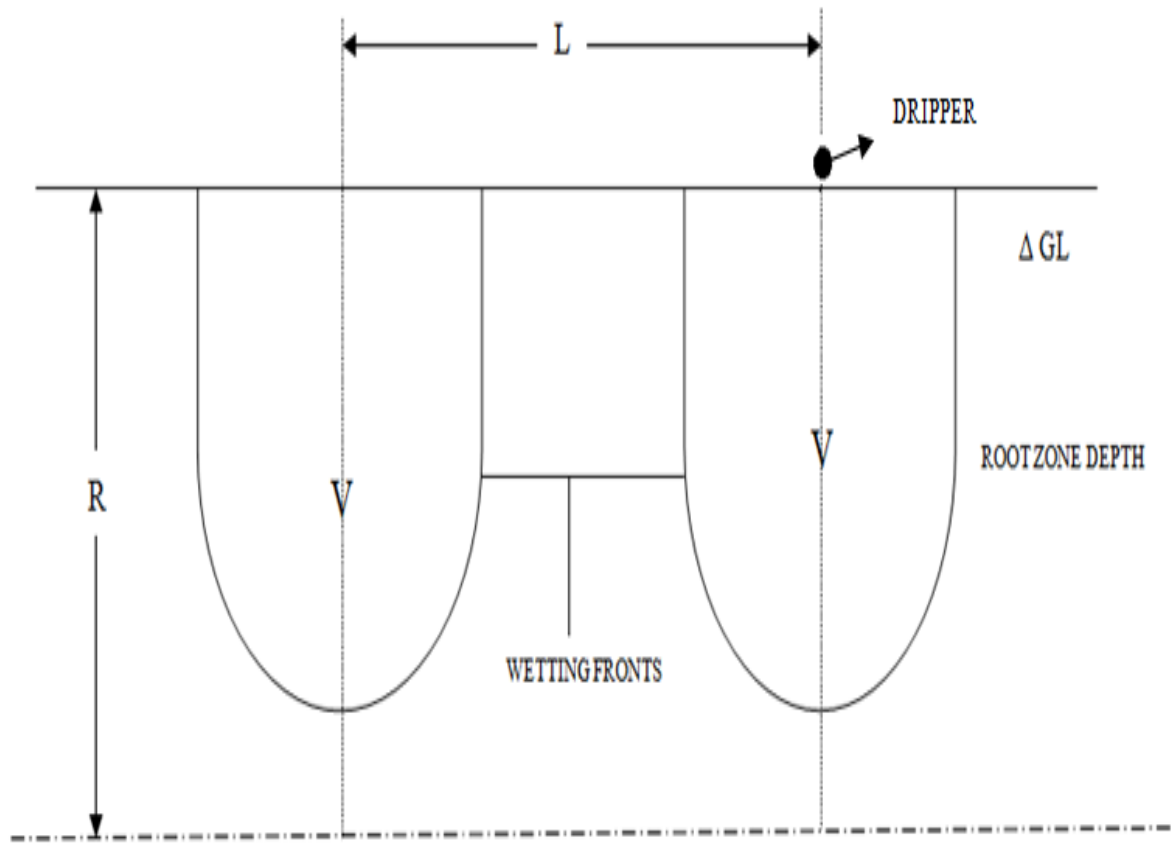


Fig.4 Horizontal advance of water Vs. time for sandy loam soil

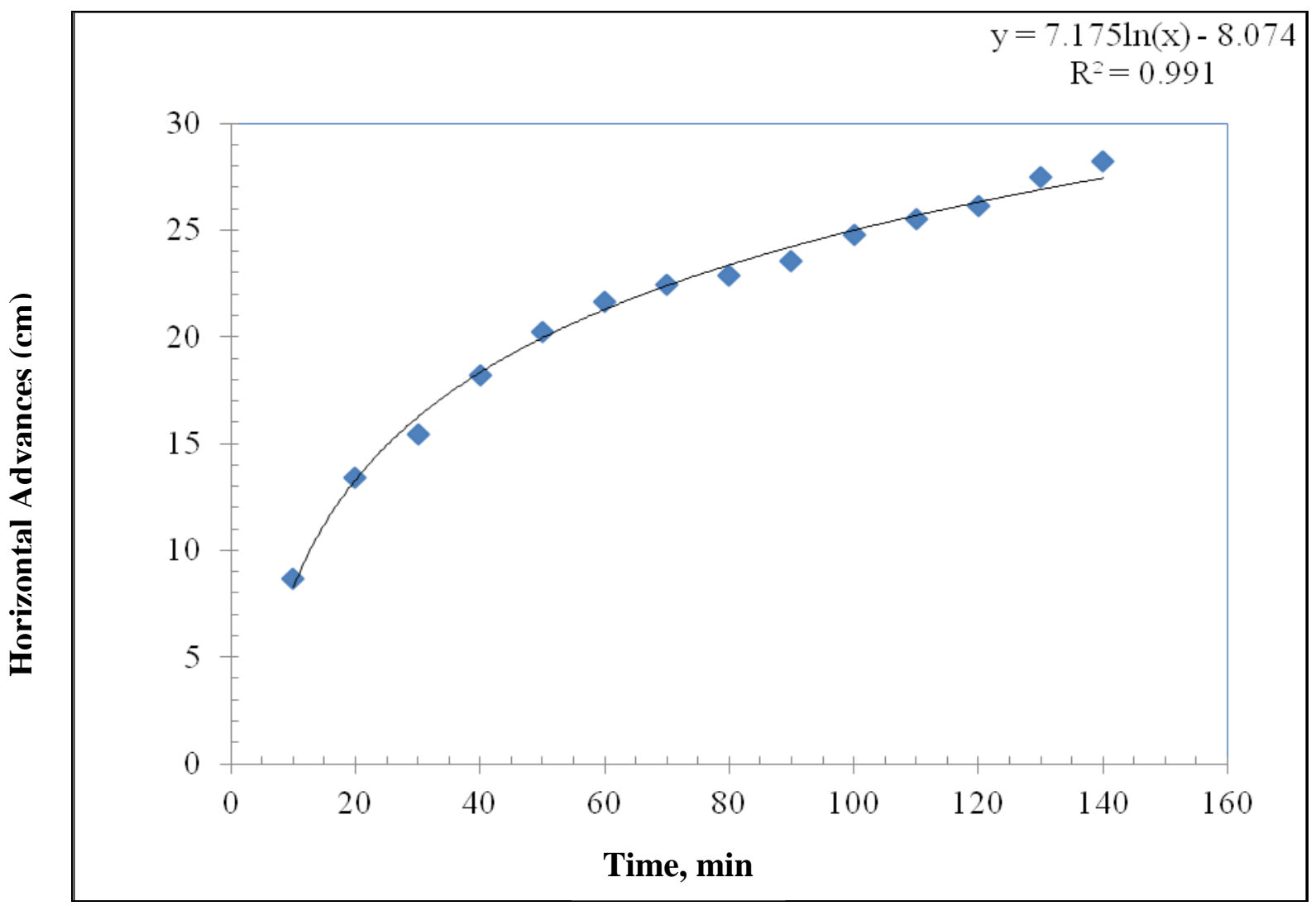

Fig.5 Vertical advance of water Vs. time for sandy loam soil

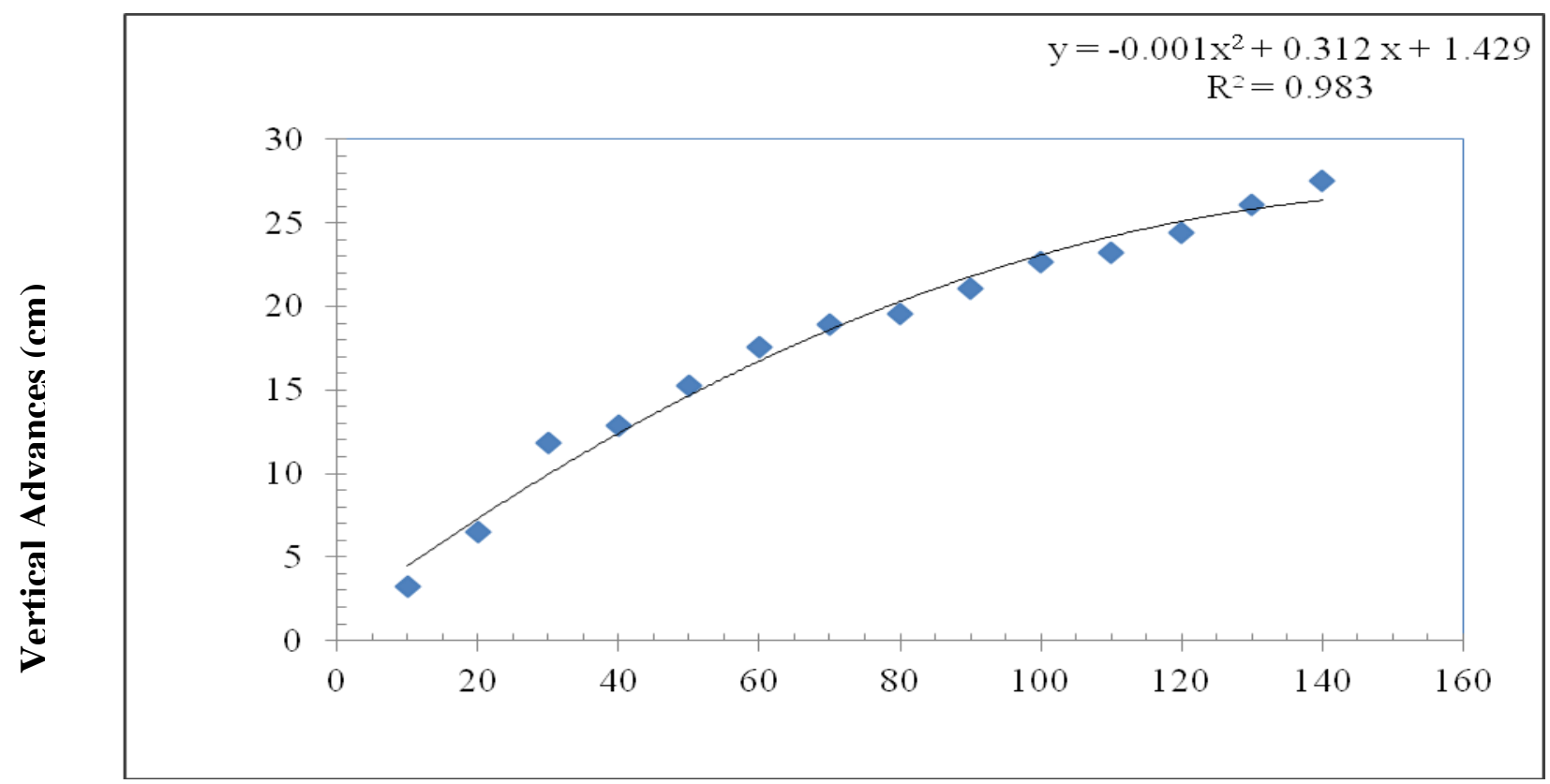

Time, min 
The profile of water movement under a point source is elliptical in case sandy soil. It is represented in the Figure 3.

\section{Moisture distribution pattern}

Moisture distribution pattern observed at various time intervals during and after irrigation for sandy loam soil are presented in Table 2.

\section{Prediction of horizontal water movement}

The observation of horizontal advancement of the sandy loam soil is plotted against the time. The different equations were developed for predicting horizontal water advance. From Table 5, the logarithmic model is used for predicting horizontal water advance which obtained highest regression co-efficient. The fitting curves along with observed points are depicted in Figure 4.

Fitting equation developed as given below.

$\mathrm{Y}=\mathrm{Y}=7.175 \ln (\mathrm{x})-8.074$ Eqn.2

$\mathrm{R}^{2}=0.991$

Where,

$\mathrm{Y}=$ Horizontal advance $(\mathrm{cm})$

$\mathrm{X}=$ Elapsed time, min

$\mathrm{R}=$ regression co-efficient.

Using the above equation the values of horizontal water advance of wetting front were predicted for the sandy soil is given in Table 4. It was observed that there was no significant difference in observed and calculated values of horizontal water advance. Further chi-square test was applied to examine the goodness of fit of the predicted values with observed values. As judged by the chi-square value the agreement between the observed and predicted horizontal advance is very good. So the developed equations can be used for the prediction of horizontal water advance for sandy loam soils. By seeing of horizontal water movement, we go for spacing of drippers.

\section{Prediction of vertical water movement}

The observation of vertical advancement of the sandy loam soil is plotted against the time. The different equations were developed for predicting vertical water advance. From Table 5 , the polynomial model is used for predicting horizontal water advance which obtained highest regression co-efficient. The fitting curves along with observed points are depicted in Figure 5.

Fitting equation developed as given below.

$\mathrm{Y}=\mathrm{Y}=-0.001 \mathrm{x}^{2}+0.312 \mathrm{x}+1.429$ Eqn. 4.2

$\mathrm{R}^{2}=0.983$

Where,

$\mathrm{Y}=$ Vertical advance $(\mathrm{cm})$

$\mathrm{X}=$ Elapsed time, $\min$

$\mathrm{R}=$ regression co-efficient.

Using the above equation the values of vertical water advance of wetting front were predicted for the sandy soil is given in Table 5. It was observed that there was no significant difference was observed and calculated values of vertical water advance. Further chi-square test was applied to examine the goodness of fit of the predicted values with observed values. As judged by the chi-square value the agreement between the observed and predicted vertical advance was very good. So the developed equations can be used for the prediction of vertical water advance for sandy loam soils. Based on vertical water movement, we know the depth $(\mathrm{mm})$ of irrigation with respect to time. 


\section{References}

Acar, B., Topak, R. and Mikailsoy. F. (2009) Effect of applied water and discharge rate on wetted soil volume in loam or clay-loam soil from an irrigate trickle source, African J. Agricultural Research, 4(1): 49-54.

Addiscott, T.M. (1996) Fertilization and nitrate leaching. Issues in Environmental Sciences and Technology, 5: 1-26.

Allen, R.G., Pereira, L.S., Rose, D. and Smith, M. (1998) Crop Evapotranspiration-Guidelines for Competing Crop Water Requirements, FAO Irrigation and Drainage Paper.

Al-Qinna, M.I. and Abu-Awwad, A.M. (2001) SW-Soil and Water: Wetting patterns under trickle source in arid soils with surface crust, J. Agricultural Engineering Research, 3: 301-305.

Angus, J.F. and van Herwaarden, A.F. (2001) Increasing water use and water use efficiency in dry land wheat, Agron. J., 93: 290-298.

Assouline, S., Cohen, S., Meerbach D., Harodi, T. and Rosner, M. (2002) Microdrip irrigation of field crops: Effect on yield, water uptake, and drainage in sweet corn, Soil Sci. Soc. Am. J., 66:228-235.

Clark, C.A., Sranley, F.S. and Zaaueta, F.S. (1993) Qualitative sensing of water movement from point-source emitter on a sandy soil, Transactions of ASAE, 9(3): 299-303.

Coelho, E.F. and Or, D. (1996) A parametric model for two-dimensional water uptake by corn roots under drip irrigation, Soil Sci. Soc. Am. J., 60: 1039-1045.

Ebdon, J.S., Petrovic, A.M. and Dawson, T.E. (1998) Relationship between carbon isotope discrimination, water use efficiency, and evapotranspiration in
Kentucky bluegrass, Crop Sci., 38: 157162.

Ehdaie, B., Hall, A.E., Farquhar, G.D., Nguyen, H.T. and Waines J.G. (1991) Water use efficiency and carbon isotope discrimination in wheat, Crop Sci., 31: 1282-1288.

El Hafid, R., Smith, D.H., Karrou, M. and Samir, K. (1998) Root and shoot growth, water use and water use efficiency of spring durum wheat under early-season drought, Agronomies, 18: 181-195.

Elmaloglou, S. and Diamantopoulos, E. (2008) The effect of intermittent water application by surface point source on the soil moisture dynamics and on deep percolation under the root zone, Computer and Electronics in Agriculture, 62(2): 266-275.

Freed, R.P., Eisensmith, S.P., Goelz, S., Reicozky, D., Smail, W.W. and Woberg, P. (1987) MSTATC. A Software Program for Design, Management and Analysis of Agronomic Research Experiments, Dept. Crop and Soil Sci. Michigan State University, MI, USA.

Hachum, A.Y., Willardson, L.S. and Alfaro, J.F. (1976) Water movement in soil from trickle source, J. Irrigation and Drainage Division, 102(2): 179-192.

Jiu-Sheng, L.I., Hong-Yan, J.I., Bei, L.I. and Yu-chun, L.I.U. (2007) Wetting patterns and nitrate distributions in layeredtextural soils under drip irrigation, Agricultural Sciences in China, 6: 970980. 160 Water Distribution Patterns of Drip Irrigation.

Levine, I., van Rooyen, P.C. and van Rooyen, F.C. (1979) The effect of discharge rate and intermittent water application by point-source irrigation on soil moisture distribution pattern, Soil Soc. Am. J., 43: 8-16. 
Martin, B. and Thorstenson, Y.R. (1988) Stable carbon isotope composition (d13C), water use efficiency, and biomass productivity of Lycopersicon esculentum, Lycopersicon pennellii, and the F1 hybrid, Plant Physiol., 88: 213 217.

Mohamed, A.R.A.G. and Abdel Monem, M. (1994) Varietal difference in wheat for water and nitrogen use efficiency as determined by stable isotops $\mathrm{C}-13$ and N-15, Egypt. J. Agron., 19: 47-64.

Nageswara Rao, R.C., Williams, J.H., Wadia, K.D.R., Hubick, K.T. and Farquhar, G.D. (1993) Crop growth, water-use efficiency and carbon isotope discrimination in groundnut (Arachis hypogaea L.) genotypes under end-of season drought conditions, Ann. Appl. Biol., 122: 357-367.

Nakayama, F.S. and Bucks, D.A. (1986) Trickle irrigation for crop production design, operation and management, Development in Agricultural Engineering, 9: 387.

Ragheb, H.M.A. (1997) Irrigation and fertilization management for yield maximization of drip irrigation potato grown on a sandy calcareous soils, Proceedings of the First Scientific Conference of Agricultural Science, Faculty of Agric, Assiut Univ. Assiut, 13-14, December.

Shlmpel, N.S., Katsuyuki, S., Junchl, K. and Shinji, S. (2002) Soil water movement under micro-drip using a perforated tube, J. Japanese Society of Soil Physics, 91: 30-47.

Simonne, E., Studstill, D. and Hochmuth, R.C. (2006) Understanding water movement in mulched beds on sandy soils: An approach to ecologically sound fertilization in vegetable production, ISHS Acta Horticulturae 700: International Symposium Towards Ecologically sound Fertilisation Strategies for Field Vegetable Production.

Stewart, W.B. (2001) Balanced Fertilization Increases Water Use Efficiency, Regional newsletter published by the Potash and Phosphate institute (PPI).

Tripathi, R. P. and Mishra, R. K. (1986) Wheat root growth and seasonal water use as affected by irrigation under shallow water table conditions, Plant and Soil, 92: 181-188.

Van den Boogaard, R., Veneklaas, E.J., Peacock, J.M. and Lambers, H. (1996) Yield and water use of wheat (Triticum aestivum) in a Mediterranean environment: Cultivar differences and sowing density effects, Plant Soil, 181: 251-262.

Virgona, J.M., Hubick, K.T., Rawson, H.M., Farquhar, G.D. and Downes, R.W. (1990) Genotypic variation in transpiration efficiency, carbon-isotope discrimination and carbon allocation during early growth in sunflower, Aust. J. Plant Physiol., 17: 207-214.

Zhange, H., Oweis, T.Y., Garabet, S. and Pala, M. (1998) Water-use efficiency and transpiration efficiency of wheat under rain-fed conditions and supplemental irrigation in Mediterranean-type environment, Plant Soil, 201: 295-305

\section{How to cite this article:}

Mallikarjun Reddy, M.S. Ayyanagowdar and Nemichandrappa, M. 2018. Characterize the Moisture Distribution Pattern in Drip Irrigation under Sandy Loam Soil. Int.J.Curr.Microbiol.App.Sci. 7(04): 2915-2923. doi: https://doi.org/10.20546/ijcmas.2018.704.332 